\title{
'If you pay, we'll operate immediately'
}

William L Miller, Åse B Grødeland and Tatyana Y Koshechkina University of Glasgow, Glasgow

\begin{abstract}
Objectives-To study the attitudes of health care staff in four postcommunist countries towards taking gifts from their clients — and their confessed experience of actually taking such gifts.

Design-Survey questionnaire administered to officials including health care staff, supplemented by focus-group discussions with the general public. Setting - Ukraine, Bulgaria, Slovakia and the Czech Republic.

Participants-A quota sample of 1,307 officials including 292 health care staff, supplemented by stratified national random samples of 4,778 ordinary members of the public and in-depth interviews or focus-group discussions involving another 323. Main measurements-Explicit justifications and willingness to accept offers, reported frequency of offers, and personal confessions to accepting "money and expensive presents" as well as smaller gifts.

Results-Health care staff were far more inclined than the average official or public servant to accept "money or an expensive present" if offered, far more inclined to justify asking clients for "extra payments", and far more inclined to confess that they had actually taken gifts from clients recently. Fudged by their own confessions, hospital doctors were only rivalled by traffic police and customs officials for taking money or expensive gifts from their clients.

Conclusions-Poor pay does not explain why doctors so often took large gifts from their clients. Moral self justification, opportunity, and bargaining power are much more effective explanations.

(Fournal of Medical Ethics 2000;26:305-311)
\end{abstract}

Keywords: Gifts; justification; gratitude; extortion; confession

\section{Introduction}

Health care was in theory free in communist Europe but in practice contributions towards hospital costs were already widespread under communism. On the basis of anecdotes, press reports and personal experience Simis claimed even in 1982, that: "in most segments of the state medical system, which is part of the lives of all Soviet citizens, corruption has become an everyday experience over the past quarter of a century". Tichtchenko notes that Soviet health care was "free to a very limited extent of unusually low quality average services ... it had become a common practice for physicians to receive money or goods as an additional, under the table payment for their services". ${ }^{2}$

Such contributions apparently increased after the fall of communism. Blasszauer asserts that "the postcommunist countries ... are suffering from a moral crisis .... The Hungarian health care system is plagued with the practice of tipping, which is often nothing else but bribery, an under-thecounter payment. It has so deeply penetrated the system that no reform seems likely to succeed". ${ }^{3}$ Borissov and Rathwell refer to the "widespread use of baksheesh or unauthorised payments" in postcommunist health care systems. ${ }^{4}$ In a review article on postcommunist health services throughout central and eastern Europe for the Fournal of Epidemiology and Community Health, McKee claimed: "most services are theoretically free at the point of service [but] there is a large black economy, with extensive use of tips and gifts to heath care staff, contributing up to 30 per cent of their total salary". $\mathrm{He}$ did not produce direct evidence for this claim but Delcheva et al later noted "extensive anecdotal evidence that the increasing budgetary gaps are being filled by informal or under-the-table payments" and quoted a 1994 Bulgarian survey in which 43 per cent of the public "had paid for [health] services that were officially free".

In our own previous study of four countries in postcommunist Europe a majority of the public told us it was more likely than not that "a person seeking something to which they were entitled by law" would none the less "have to offer money, a present or a favour" to get help from most kinds of officials or public employees. In this survey, doctors tied for top place on the list of those whom citizens told us they would have to bribe in this way, though there was some cross-national variation. Doctors were almost half-way down the list in the Czech Republic but they came top in each of the other three countries, if sometimes by a very small margin. ${ }^{7}$ Some other surveys have put doctors in these countries further down the list though their questions have been significantly different from ours. In February 1999 for example, Coalition 2000's tracking survey put Bulgarian doctors in second place, well behind customs officials, and in April and September it put doctors still lower down the list (private communication from Vitosha Research). But although these tracking surveys were done by Vitosha Research, who also carried out our own Bulgarian fieldwork, they used a significantly different question which focused on public perceptions of the numbers of "corrupt" officials rather than on the need for clients to offer gifts. And in all of these surveys, doctors were rated above the average for "corruption".

Focus groups and in-depth interviews with the general public supported allegations about the need to bribe health care staff: "Doctors take presents for 
granted". (Striy, Western Ukraine-medium town) "They said that I needed an operation-it would cost 50 dollars. When I went in the doctor was absolutely calm 'I have this tariff -100 dollarsyou do what you want.' It's already gone up!” (Kyiv, Ukraine-capital) "We paid the doctor for the medical examination. And he himself said: 'You come from the collective farm and you didn't bring anything?' We didn't bring anything-no milk, no sour cream, nothing. So what?-I don't get a medical examination after all?" (Nikolayevka, Eastern Ukraine-village) "Doctors will even take from old ladies, even an egg is acceptable, everything, a jar of something, antiques" (Olesnice, Czech Republicvillage).

Such public perceptions might be dismissed as gossip however, not least because many members of the public have little direct experience of dealing with certain kinds of official. In our surveys for example, 63 per cent claimed direct experience of dealing with heath care officials but only 11 per cent with customs officials. To check public perceptions against experience, and to get the views of officials themselves, we undertook a new study based on interviews with junior officials or public employees themselves. In these interviews hospital doctors topped the list of those who confessed that they had recently accepted "money or expensive gifts" from clients.

\section{New interviews}

These new interviews with officials do more, however, than corroborate public perceptions. First, it was never quite clear to the citizen whether "informal" payments in the health services went into the pockets of the staff or went to provide otherwise unavailable drugs and equipment (which may explain some of the differences between Vitosha Research's tracking surveys and the original survey they did for us). The ambiguity was illustrated by a participant in one of our focus groups who paid for, and received, an anaesthetic during dental surgery only when he could stand the pain no longer. Our new survey of officials eliminates that ambiguity: the doctors, nurses and hospital administrators and other officials that we interviewed discussed, and admitted accepting, personal gifts, not charges for hospital supplies nor even general donations to hospital funds.

Second, and more important, our interviews with officials themselves add a unique insight into officials' motivations, which cannot be gleaned from an analysis of public perceptions. The primary purpose of this paper is therefore not to reiterate the oft-repeated claim that doctors frequently take gifts and bribes from their clients in postcommunist Europe. Instead, our primary purpose is to see what our survey of officials can tell us about the reasons why doctors were so much more likely than most other officials we interviewed to confess that they took "money or expensive presents" from their clients-even in countries where overall levels of bribe-taking were notoriously high.

\section{Subjects and methods}

This paper is based primarily on interviews with officials in Ukraine, Bulgaria, Slovakia and the Czech Republic. We used a very tight interlocking quota to ensure an even spread across different kinds of official and, at the same time, crossnational comparability. In each country we aimed for 60 interviews in each of five broad categories of state services. More precisely we aimed for 20 interviews in each of three occupations within each service category: doctors, nurses, and hospital administrators (within health services); university teachers, university administrators, and school teachers (within education services); officials in pensions, benefits, and housing offices (within welfare services); traffic police, ordinary police, and police administrators (within police services), and court officials, customs officials, and passport officials (within a more heterogeneous category of legal services). Our interviewers exceeded their targets, producing 1,307 interviews in all, including 292 in health services, 85 of them with hospital doctors. We have downweighted the data to have the equivalent of exactly 20 interviews with each specific occupation, in each country.

Ensuring that the quota structure of officials is exactly the same in each country allows us to average our findings across countries, focusing attention away from the admittedly fascinating crossnational variations and onto the differences between types of official. No type of official occurs more frequently in the sample drawn from one country rather than another. Consequently the difference between two types of official in the combined data set is guaranteed to be the exact average of the differences between these two types of official within each of the four countries.

In addition, interviews with officials were spread across the regions within each country, and across different types of settlement-including small towns and rural areas as well as large towns and the capital city (though the quotas recognised, for example, that there were very few universities in villages!). Interviewers were also instructed to obtain a mix of ages and genders where possible. While there can be no absolute guarantee that any quota sample is fully representative (and refusal rates are not appropriate for quota samples) we think this was the most effective way to construct a sample for a comparative study of officials. Random sampling from government lists of officials would not have been feasible and help from the authorities, even if available, would have raised fears about confidentiality and thereby prejudiced participants' responses.

Questionnaires were written at Glasgow University. Translation, piloting, sampling, and interviewing was carried out by professional agencies working to ESOMAR standards: OPW Prague under the direction of Ladislav Koppl, MVK Bratislava under the direction of Pavel Haulik, CSD Sofia under the direction of Alexander Stoyanov, and GfK-USM Kyiv under the direction of Tatyana Koshechkina. Their questionnaire translations were checked by 
native speakers in Glasgow and revised in consultation with the agencies. The questionnaire was cut sharply after the pilot stage to avoid respondent fatigue but still contained over 160 fully-structured questions. Each agency had a large professional field force, spread across the country, which was experienced in quota sampling locally. Interviewing, face-to-face, was carried out between July and September 1998.

\section{Earlier work}

For comparison we also make occasional reference to our earlier public opinion studies in the same four countries. Fieldwork was conducted by the same agencies. We used both quantitative and qualitative methods. The quantitative research was based on representative samples of the adult population (aged 18 plus). These were multistage random samples, strictly representative of the regions, and of rural as well as urban areas, within each country. There were 721 sampling points and 4,778 interviews in all. (The project also included an additional 1,272 interviews in ethnic minority areas but they are outside the scope of this paper.) At each sampling point respondents were selected by the "random walk" method, except in Bulgaria where respondents were selected from electora lists. Just over 17 per cent of selected respondents refused to take part. Interviewing, face-to-face, took place between November 1997 and February 1998, using a fully-structured questionnaire of 215 questions.

The qualitative research which preceded the quantitative studies consisted of 26 focus-group discussions (with 187 participants) and 136 in-depth interviews carried out between July and October 1996. Like most qualitative research, this aspect of our study aimed more at providing understanding, illustration, meaning and interpretation rather than representative findings. The scale of qualitative work is usually far too small to provide any guarantee of that. We have used our large-scale representative surveys to quantify our findings and quotations from our qualitative fieldwork to illustrate and interpret them.

None the less, we did try to make even the qualitative aspects of our study as representative as possible by holding an unusually large number of focus-group discussions and ensuring that within each country they ranged from capital cities down to villages and also that they ranged widely across the regions within each country. (In addition, one focus group in each country except the Czech Republic was held in an area where an ethnic minority was concentrated.) Participants were selected by the local staff of the survey agencies, all of which had very extensive experience in focusgroup research. The aim was a spread of occupations, ages and genders except that in each of the capital cities we held one focus group with a mixed group of participants, and a second restricted to highly educated participants. Discussions were chaired by the agencies' specialist and very experienced "focus-group moderators".
Both the focus-group discussions and the in-depth interviews were semi-structured. Both were based on the same 11-page schedule of questions/topics, written in Glasgow and translated by our survey agencies with the translation checked and corrected in Glasgow. Simultaneous translation was provided for the authors who attended the majority of the focus groups. All 26 were videorecorded, and transcripts made in the vernacular and in English by our survey agencies.

We used SPSS for the quantitative analysis. Although significance tests are not strictly appropriate for quota samples we have included them (based on the F test) as a convenient heuristic guide. For the qualitative data we used QSR:NUD・IST (Revision 3) to analyse the English-language versions of the focus-group transcripts and in-depth interview reports. ${ }^{8}$ Although we have used selected quotations from the qualitative research only to illustrate findings from the quantitative research in this paper, we have presented more extensive and systematic analysis of the qualitative research elsewhere..$^{9-11}$

\section{Results}

In our survey of officials, we asked: "If a member of the public offered you money or an expensive present for solving their problem would you ...

(i) welcome it as a token of thanks

(ii) reluctantly accept it, because it would be impolite to refuse

(iii) reluctantly accept it, because official salaries are so low that you could not afford to refuse

(iv) feel offended and refuse

(v) refuse for other reasons."

On their own admission many officials (17 per cent) were willing to accept "money or expensive presents" from clients "if offered". But doctors (32 per cent), nurses (28 per cent) and hospital administrators (26 per cent) topped the list. The balance of reasons for accepting gifts varied. Nurses were twice as likely to cite low salaries as other reasons, but doctors and hospital administrators put about equal weight on low salaries and other reasons.

Health care workers also topped the list of those who confessed that they had actually accepted a gift from a client in recent years. We put three questions in quick succession to all officials. They were designed to model the way that we might, in a less structured interview, persist in an attempt to get a clear answer on a sensitive topic. First: "In the last few years, say the last five years, did you ever accept a present from someone whose problem you dealt with as part of your official duties?" Then, even if they had answered "no" to that first question we asked: "If you did accept something, was that only after you had solved the person's problem?" And even if they still denied accepting anything we asked: "If you did accept something, was that only a small present-flowers, chocolates, or a bottle for example, or was it something more than that?" Through this sequence of three questions about 
Table 1 By their own account: whether officials 'would take' or 'had taken' gifts

\begin{tabular}{|c|c|c|c|}
\hline & \multicolumn{3}{|c|}{$\begin{array}{l}\text { Would accept money or an expensive present, if } \\
\text { offered }\end{array}$} \\
\hline & $\begin{array}{l}\text { as token of thanks } \\
\text { / impolite to refuse } \\
\%\end{array}$ & $\begin{array}{l}\text { could not afford } \\
\text { to refuse } \%\end{array}$ & Total \% \\
\hline \multirow{7}{*}{$\begin{array}{l}\text { Doctors } \\
\text { Nurses } \\
\text { Hospital } \\
\quad \text { administrators } \\
\text { All officials }\end{array}$} & 14 & $18^{\star \star}$ & $32^{\star \star}$ \\
\hline & 9 & $19^{\star \star}$ & $28^{\star}$ \\
\hline & & & \\
\hline & $14^{\star}$ & 12 & $26^{\star}$ \\
\hline & 8 & 9 & 17 \\
\hline & \multicolumn{3}{|c|}{ Had recently accepted: } \\
\hline & $\begin{array}{l}\text { only a small } \\
\text { present } \%\end{array}$ & $\begin{array}{l}\text { something } \\
\text { more } \%\end{array}$ & Total \% \\
\hline Doctors & $73^{\star \star}$ & $16^{\star \star}$ & $89^{\star \star}$ \\
\hline Nurses & $74^{\star \star}$ & 2 & $76^{\star \star}$ \\
\hline \multicolumn{4}{|l|}{ Hospital } \\
\hline administrators & 60 & $10^{\star}$ & $70^{\star}$ \\
\hline All officials & 53 & 5 & 58 \\
\hline
\end{tabular}

Notes:

1. This and subsequent tables are based on a total of 1,307 interviews with junior officials and state employees, including 85 with hospital doctors, 125 with nurses and 82 with hospital administrators.

2 . In this and subsequent tables a single asterisk $\left({ }^{\star}\right)$ indicates a statistically significant difference from the average for all other officials (taken together) at the $95 \%$ level. A double asterisk ( $\left.{ }^{\star \star}\right)$ indicates a statistically significant difference at the $99 \%$ level. Significance levels have been calculated in the conventional way using SPSS. Strictly speaking such significance levels should not be applied to quota samples but they may none the less be a useful heuristic guide.

gift-taking, the percentage of officials who confessed to accepting gifts from their clients increased by over 20 per cent. So that in answer to the third question, fully 58 per cent of officials confessed that they had accepted something, although only five per cent confessed that it was "something more" than "a small present-flowers, chocolates, or a bottle for example". Although the "something more" was formally defined only implicitly in the question by what it was not, it can reasonably be equated with the phrase "money or an expensive present" which we used in various other questions throughout the interview.

Doctors were 31 per cent more likely than the average official to confess to accepting some kind of gift, and over three times as likely as the average official to confess to accepting "something more". Only five per cent of Czech doctors confessed to accepting "something more" than a small gift but between 18 per cent and 21 per cent in the other countries, averaging 16 per cent. Nurses differed sharply from doctors in the size of the gifts that they reported. By their own account, nurses were far above average in accepting small presents, but slightly below average in accepting anything more than that. Conversely, traffic police were below average in accepting small gifts, but they came second only to doctors in admitting that they had received "something more".
Why did officials take 'gifts' from clients? Some clients gave presents (usually small ones) out of gratitude: "When you see the demanding work of nurses-you feel like giving them something. I gave some coffee to nurses". (Bratislava, Slovakiacapital) "The doctor told me I was not expected to offer him anything, but I insisted, I was doing it out of gratitude." (Tenevo, Bulgaria-village) But others were not grateful: "You give only if you have been given some hint that they want something." (Kurdjali, Bulgaria - a medium town where 65 per cent were ethnic Turks according to the 1992 census.) "I am a medical woman myself, I am friends with the dentist and the nurse and yet I've got to invite them to a coffee shop and treat them. I wonder what people without connections can do?" (Yambol, Bulgaria - medium town)

We asked whether officials generally took gifts mainly because of greed, or poor pay, or importunate clients. Officials themselves put the blame mainly on "poor pay" but the public put that explanation in third place, well below "greedy officials" or even "clients desperate to buy favours".

\section{Poor pay?}

But the poor pay thesis is worth investigating further. Other things being equal, it is plausible that poor pay might encourage officials to take bribes, even if it were not the only nor even the main reason for bribe-taking. Most people in postcommunist Europe are badly paid of course. But could unusually poor pay explain why those in the health service accepted gifts more frequently than other officials?

Some of the public sympathised: "Doctors work for symbolic wages." (Sofia, Bulgaria-capital) "Insufficient salaries, that's the cause of all that bribing." (Bratislava, Slovakia-capital) "If they paid a doctor well ... he would be afraid to lose his position." (Khartsysk, Eastern Ukraine-medium town) But others were doubtful: "Some [doctors] would go on accepting bribes even if their salaries were adequate." (Bratislava, Slovakia - capital) And more categorically, a sceptical nurse suggested that "wage increases would not affect bribe-taking." (Dolny Kubin, Slovakia - village)

Nurses complained far more than average that they "could not live on their salary". But doctors and hospital administrators were about average.

Table 2 Was greed, poor pay, or importunate clients the main reason why officials accepted gifts?

\begin{tabular}{|c|c|c|c|}
\hline & \multicolumn{3}{|c|}{$\begin{array}{l}\text { Main reason why officials take presents and } \\
\text { bribes is... }\end{array}$} \\
\hline & $\begin{array}{l}\text { officials are } \\
\text { greedy } \%\end{array}$ & $\begin{array}{l}\text { officials are } \\
\text { badly paid \% }\end{array}$ & $\begin{array}{l}\text { people are } \\
\text { desperate to } \\
\text { buy favours \% }\end{array}$ \\
\hline Doctors & 14 & 56 & 31 \\
\hline Nurses & 19 & $38^{\star \star}$ & $43^{\star}$ \\
\hline Hospital administrators & 8 & 59 & 33 \\
\hline All officials & 13 & 55 & 32 \\
\hline $\begin{array}{l}\text { By contrast-the } \\
\text { opinion of the public }\end{array}$ & 39 & 25 & 36 \\
\hline
\end{tabular}


Table 3 Poor pay?

\begin{tabular}{|c|c|c|c|}
\hline & $\begin{array}{l}\text { Cannot live } \\
\text { on salary \% }\end{array}$ & $\begin{array}{l}\text { Have } \\
\text { another } \\
\text { source of } \\
\text { income } \\
\text { beyond } \\
\text { salary \% }\end{array}$ & $\begin{array}{l}\text { Family income } \\
\text { is enough for } \\
\text { 'fair'or 'good' } \\
\text { standard of } \\
\text { living \% }\end{array}$ \\
\hline Doctors & 40 & $44^{\star \star}$ & $43^{\star}$ \\
\hline Nurses & $60^{\star \star}$ & 28 & 25 \\
\hline Hospital administrators & 44 & 35 & 25 \\
\hline All officials & 41 & 26 & 33 \\
\hline $\begin{array}{l}\text { By contrast-the } \\
\text { economic condition of } \\
\text { the public }\end{array}$ & na & na & 26 \\
\hline
\end{tabular}

Many people in postcommunist Europe (including a quarter of the "officials" in our survey) have significant "second incomes". Nurses were about average in this respect but hospital administrators were above average and doctors were 18 per cent more likely than the average official to report a second income. (Only university teachers were more likely than doctors to report a second income.) Doctors were also well above average in the extent to which they said their "family income" was enough for a "fair" or "good" standard of living (exceeded only, and then only marginally, by customs officials), while nurses and hospital administrators were somewhat below the average.

Taking all these indicators together, its is clear that doctors were under much less economic pressure than the average official, that nurses were under more pressure than average, and that hospital administrators were not too far away from the average. So it is unlikely that poor pay can explain why doctors accepted more than a small present so much more frequently than others.

Indeed, the general idea that poor pay explains gift- or bribe-taking is sharply contradicted in our survey. Poor pay clearly did make our officials more willing to accept gifts "if offered". But amongst those who were willing to accept, it was those with the highest salaries and the best family incomes who actually accepted them more frequently-no doubt because they had the most power to help clients, and thus the most power to extort.

\section{Moral self justification?}

A second possible explanation for the high levels of gift-taking in health services is a "culture of justified gift-taking" which is more deeply entrenched in the health services than in other public services. Our earlier qualitative studies had indicated that health care staff were often direct in their demands: "The surgeon said the patient must give so much to the surgeon, so much to the neuropathologist, so much to the anaesthesiologist, and so much to the assistant. He directly said how much."(Horodok, Western Ukraine-small town) "You enter the doctor's room, and he sends the nurse away on some errand and before even starting says, 'I charge 5,000 levs, or 10 marks. Will that be all right with you, or not?' And you cannot say no, since he is not going to examine you. Or if it's not money, he says 'Two kilograms of cheese, or lamb or pork'."(Tenevo, Bulgaria-village; in 1999 the currency was reformed so that 1,000 old levs became one new lev.) And in the patient's view doctors were often quite shameless about it: "This doctor took the money, an amazing sum, and the wife died. He knew she was dying but he took the money." (Khartsysk, Eastern Ukraine-medium town)

We now explored whether officials themselves thought "it would be right" for an official to "ask for something" from a client in return for "extra work". Doctors and nurses came top of the list. Nurses were almost twice as likely as the average official to assert such a right, and doctors well over twice as likely.

We also asked officials themselves whether they thought their government regarded gifts of "money or expensive presents" as a "corrupt practice to be eliminated", as "unfortunate but unavoidable" in the short term, or even as "an informal way of paying officials". In Bulgaria, a new Law on Medical Associations (July 1998) came into force during our interviews with officials and a more general Law on State Officials (August 1999) a year later. Similar laws and decrees have been issued in other countries. But the implementation and enforcement of laws in postcommunist Europe is more important than their enactment and it takes time for laws to influence perceptions. About half the officials we interviewed (slightly less than half in the Czech Republic and almost two-thirds in Ukraine) expressed the belief that their government was at least willing to tolerate such gifts as unavoidable in the short term. Doctors were the most likely of all officials to feel that their government was willing to tolerate gifts as informal salaries: 71 per cent of them compared to 54 per cent of all officials. Nurses were only slightly above average on this, and hospital administrators slightly below.

Altogether there seems clear evidence of a distinctive culture of self-consciously justified gift-taking amongst doctors and nurses, and most especially amongst doctors.

\section{Opportunity?}

There is a third possible explanation: opportunity. Doctors were twice as likely as the average official to report that their clients frequently offered them both "small presents" and "money or expensive gifts". Nurses and hospital administrators were close to the average, though nurses, unlike the administrators, reported getting offers of small gifts very slightly more than average while getting offers of "money or expensive gifts" very slightly less than average.

Only two other sets of officials reported offers of "money or expensive presents" almost as frequently as doctors: traffic police and customs officials. What have doctors, traffic police and customs officials got in common apart from these offers of money from clients? And what distinguishes them from others in similar but distinct occupations who did not receive such offers so frequently? What distinguishes 
Table 4 Moral self-justification?

\begin{tabular}{lll}
\hline & \multicolumn{2}{l}{$\begin{array}{l}X 2: \text { For 'extra work' it would be right } \\
\text { to... }\end{array}$} \\
\cline { 2 - 3 } & $\begin{array}{l}\text { ask for } \\
\text { something \% }\end{array}$ & $\begin{array}{l}\text { accept (or ask for) } \\
\text { something \% }\end{array}$ \\
\hline Doctors & $35^{\star \star}$ & $78^{\star \star}$ \\
Nurses & $28^{\star \star}$ & $80^{\star \star}$ \\
Hospital administrators & 13 & 67 \\
All officials & 15 & 60 \\
\hline
\end{tabular}

Table 5 Officials'perceptions of their government's tolerance for gift-taking

\begin{tabular}{|c|c|c|c|c|}
\hline & \multicolumn{4}{|c|}{$\begin{array}{l}\text { The government regards low-level officials accepting } \\
\text { money or expensive presents from ordinary people } \\
\text { as... }\end{array}$} \\
\hline & \multirow{2}{*}{$\begin{array}{l}\text { intolerable } \\
\text { a corrupt } \\
\text { practice to be } \\
\text { eliminated } \\
\%\end{array}$} & \multicolumn{3}{|c|}{ tolerable } \\
\hline & & $\begin{array}{l}\text { unfortunate } \\
\text { but } \\
\text { unavoidable } \\
\%\end{array}$ & $\begin{array}{l}\text { an informal } \\
\text { way of } \\
\text { charging } \\
\%\end{array}$ & $\begin{array}{l}\text { Total } \\
\text { tolerable } \\
\%\end{array}$ \\
\hline Doctors & $30^{\star \star}$ & $47^{\star}$ & 24 & $71^{\star \star}$ \\
\hline Nurses & 41 & 41 & 18 & 59 \\
\hline \multicolumn{5}{|l|}{ Hospital } \\
\hline administrators & 50 & 33 & 17 & 50 \\
\hline All officials & 46 & 35 & 19 & 54 \\
\hline
\end{tabular}

doctors from nurses, traffic police from other police, and customs officials from passport officials?

The most obvious answer is their discretionary, unchecked power over clients for at least a short but critical time in their lives: "When the matter has to do with health, you go ahead and give bribes Health is more important than anything." (Kyiv, Ukraine-capital) "If you want it all to go well it would cost you 300 dollars."'(Sofia, Bulgaria - capital) "There are cases when people have died while raising the money."(Kurdjali, Bulgaria-medium town) "He was told he had to give 20,000 levs. $\mathrm{He}$ said he could afford only 10,000 levs. And two days later his father died.” (Tenevo, Bulgaria-village)

If nothing worse, patients had a real fear of unnecessary delays: "He had an ulcer to be operated on. One of the doctors was direct in telling him: 'If you pay, we'll operate immediately'. He couldn't pay and was sent over to the hospital in Haskovo."(Kurdjali, Bulgaria-medium town) One nurse reported: "The surgeons wanted 40,000. The woman had no money. They delayed the operation but after some time they operated. Doctors try first to get the money. If they cannot get the money, then they will do it for free." (Yambol, Bulgariamedium town)

\section{Discussion and conclusions}

Our earlier evidence from focus groups, in-depth interviews, and public opinion surveys all suggested that citizens in the countries surveyed frequently gave gifts to those who worked in health services. These new interviews with officials themselves have confirmed that those who worked in the health service were more likely than any other officials to
Table 6 Opportunity?

\begin{tabular}{|c|c|c|c|c|}
\hline & \multicolumn{2}{|c|}{$\begin{array}{l}\text { More than rarely, a } \\
\text { client offered... }\end{array}$} & \multicolumn{2}{|c|}{$\begin{array}{l}\text { At least rarely, a client } \\
\text { offered... }\end{array}$} \\
\hline & $\begin{array}{l}\text { a small } \\
\text { present } \%\end{array}$ & $\begin{array}{l}\text { money } \\
\text { or an } \\
\text { expensive } \\
\text { present \% }\end{array}$ & $\begin{array}{l}\text { a small } \\
\text { present } \%\end{array}$ & $\begin{array}{l}\text { money } \\
\text { or an } \\
\text { expensive } \\
\text { present \% }\end{array}$ \\
\hline Doctors & $57^{\star \star}$ & $21^{\star \star}$ & $90 \star \star$ & $45^{\star \star}$ \\
\hline Nurses & 33 & 7 & 75 & 23 \\
\hline $\begin{array}{l}\text { Hospital } \\
\text { administrators }\end{array}$ & 27 & 11 & 64 & 26 \\
\hline All officials & 30 & 10 & 67 & 27 \\
\hline
\end{tabular}

accept gifts, doctors most of all. And doctors were especially likely to have accepted large gifts"money or an expensive present"-from their clients.

Tichtchenko argues that what might have been justified as "resistance to the totalitarian regime" is now simply "the use of the medicalised power of the regime for individual survival or enrichment ... not a resistance to totalitarian power but its effective reinforcement and proliferation into micro and macro social relationships". ${ }^{12}$

But any programme of reform needs to take account of the reasons underlying this behaviour as well as the behaviour itself. We looked at several possibilities.

The popular excuse of poor pay does not work. Nurses were under great economic pressure, but doctors (by their own account) were not. Compared to Western doctors they were certainly poor, but not compared to many other people within their own societies. Moreover, we found that while poor pay increased willingness to accept gifts "if offered", it was the better paid amongst the willing who actually received expensive gifts from clients most frequently. The "tips" such as flowers and chocolates went to those, like nurses, who were worse paid, while the "money and expensive presents" went to the better paid elite and the powerful such as doctors.

Self-conscious moral justification, opportunity, and bargaining power were much more effective explanations. Doctors were under less economic pressure than most other officials, but they were especially likely to justify informal payments by clients for "extra work", especially likely to feel that their government tolerated informal payments, and especially likely to be offered money or expensive presents by clients. They combined a strong bargaining position with a culture that justified gift-taking to an unusual degree.

It might be argued that clients just felt uniquely grateful to doctors, and that doctors' inhibitions were overwhelmed by such gratitude. We have no direct evidence on the gratitude clients felt towards specific officials. But we did ask the public why people generally gave gifts to officials and gratitude did not figure highly. Even for gifts given after help from an official, simple gratitude was cited by only 30 per cent of the public. And for gifts given before help from an official, it was cited by a mere 12 per 
cent. The pressure to behave politely added to those figures but none the less a majority not only claimed that gifts given beforehand were extorted by officials but also that even gifts given afterwards were either extorted or given because clients feared they would need further help in the future. Health needs arouse intense emotions, but emotions of fear as well as gratitude. In the absence of clear evidence we cannot assume that clients felt uniquely grateful to doctors rather than uniquely afraid of them.

\section{Acknowledgements}

This research was funded by the Department for International Development (DFID) under grant R6455 to Miller and Koshechkina, by the Economic and Social Research Council (ESRC) under grant R222474 to Miller and Grødeland and by Glasgow University.

William L Miller, $M A$ (Edinburgh), PhD (Newcastle), FBA, FRSA, FRSE, is Edward Caird Professor of Politics, University of Glasgow. Ase B Grodeland, CandMag (Oslo), MPhil (Glasgow), PhD (Glasgow), was Co-director of this study in the Department of Politics, University of Glasgow. Tatyana Y Koshechkina, five-year degree in Psychology (Kyiv State), $M A$ (Kent), was Honorary Fellow in the Department of Politics and is now International Research Director, $G f K-G B$

\section{References}

1 Simis KM. USSR: secrets of a corrupt society. London: J M Dent, 1982:157.

2 Tichtchenko P. Corruption: the Russian experience. Bulletin of Medical Ethics 1996;121:13-18: at 14 and 15.

3 Blasszauer B. Petty corruption in health care. Fournal of Medical Ethics 1997;23:133-4.

4 Borissov V, Rathwell T. Health care reforms in Bulgaria: an initial appraisal. Social Science and Medicine 1996;42:1501-10: at 1501.

5 McKee M. Health services in central and eastern Europe: past problems and future prospects. Fournal of Epidemiology and Community Health 1991;45:260-5: at 260.

6 Delcheva E, Balabanova D, McKee M. Under-the-counter payments for health care: evidence from Bulgaria. Health Policy 1997;42:89-100: at 89 .

7 Miller WL, Grødeland ÅB, Koshechkina TY. Are the people victims or accomplices?: the use of presents and bribes to influence officials in Eastern Europe. Crime, Law and Social Change $1998 ; 29 ; 273-312$ : at 278.

8 Weitzman E. Computer programs for qualitative data analysis. London: Sage, 1995.

9 Miller WL, Koshechkina TY, Grødeland ÅB. How citizens cope with postcommunist officials: evidence from focus group discussions in Ukraine and the Czech Republic. Political Studies 1997;45:597-625.

10 Grødeland ÅB, Koshechkina TY, Miller WL. Alternative strategies for coping with officials in different postcommunist regimes: the worm's eye view. Public Administration and Development 1997;17:511-28.

11 Grødeland ÅB, Koshechkina TY, Miller WL. 'Foolish to give and yet more foolish not to take': in-depth interviews with postcommunist citizens on their everyday use of bribes and contacts. Europe-Asia Studies 1998;50:649-75.

12 See reference $2: 18$ 